\title{
Niobium and rare earth minerals from the Virulundo carbonatite, Namibe, Angola
}

\author{
L. Torró ${ }^{1}$, C. Villanova ${ }^{1}$, M. Castillo ${ }^{1}$, M. Campeny ${ }^{1}$, A. O. Gonçalves ${ }^{2}$ and J. C. Melgarejo ${ }^{1, *}$
}

1 Departament de Cristal·lografia, Mineralogía i Dipòsits Minerals, Universitat de Barcelona, c/Martí i Franquès s/n, 08028 Barcelona, Catalonia, Spain

2 Departamento de Geologia, Faculdade de Ciências, Universidade Agostinho Neto, Av. 4 de Fevereiro 7, 815 Luanda, Angola

[Received 27 January 2011; Accepted 7 July 2011; Associate Editor: Hilary Downes]

\section{ABSTRACT}

The Virulundo carbonatite in Angola is one of the largest in the world and contains pyrochlore as an accessory mineral in all of the carbonatite units (calciocarbonatites, ferrocarbonatites, carbonatite breccias and trachytoids). The primary magmatic pyrochlore is fluorine dominant and typically contains about equal molar quantities of $\mathrm{Ca}$ and $\mathrm{Na}$ at the $A$ site. High-temperature hydrothermal processes have resulted in the pseudomorphic replacement of the primary pyrochlore by a second generation of pyrochlore with less $\mathrm{F}$ and Na. Low-temperature hydrothermal replacement of the first and second generation pyrochlore, associated with quartz-carbonate-fluorite vein formation in the carbonatite, has produced a third generation of pyrochlore, with a high $\mathrm{Sr}$ content. The Sr appears to have been released by low-temperature hydrothermal replacement of the primary magmatic carbonates. Finally, supergene alteration processes have produced late-stage carbonates, goethite, hollandite and rare earth element (REE) minerals (mainly synchysite-(Ce), britholite-(Ce), britholite-(La), cerite(Ce)). Cerium separated from the other REEs in oxidizing conditions and $\mathrm{Ce}^{4+}$ was incorporated into a late generation of supergene pyrochlore, which is strongly enriched in $\mathrm{Ba}$ and strongly depleted in $\mathrm{Ca}$ and $\mathrm{Na}$.

KeYwords: Angola, carbonatite, pyrochlore, REE, magmatic, hydrothermal, weathering, Virulundo.

\section{Introduction}

THE Virulundo carbonatite is one of the largest in the world (Woolley, 2001). Its remote location in the Namib desert and the political situation in Angola has prevented the detailed study of this important carbonatite massif for many years. Geological descriptions are limited to the preliminary surveys made during Portuguese colonial times.

Recently, interest in carbonatites has increased due to their potential to produce economically valuable elements, particularly REEs and $\mathrm{Nb}$. The

* E-mail: joan.carles.melgarejo.draper@ub.edu

DOI: $10.1180 /$ minmag.2012.076.2.08 mineral assemblages and textures in a carbonatite determine its suitability for mining (e.g. Aral and Bruckard, 2008). The aim of this contribution is to provide new data on the mineralogy of pyrochlore and REE minerals in the Virulundo carbonatite.

\section{Geological setting}

The Virulundo carbonatite belongs to the ParanáNamibia-Angola alkaline-carbonatitic province, which formed during the break up of the supercontinent of Pangaea (Castorina et al., 1996; Comin-Chiaramonti et al., 1997a,b; 2007a,b; Ernst and Bell, 2010). This province is characterized by Early Cretaceous tholeiitic flood basalts and dyke swarms (133 Ma; Renne et al., 1992, 1997), which occur in close association with alkaline and alkaline-carbonatitic complexes 
ranging in age from Mesozoic to Paleogene (Castorina et al., 1996; Comin-Chiaramonti et al., 2007a,b).

In Angola, carbonatites and kimberlites are concentrated along the Lucapa structure, a riftrelated Lower Cretaceous fault system; they are mostly Early Cretaceous in age (Coltorti et al., 1993; Alberti et al., 1999). Carbonatites are concentrated in the southwest of the structure and kimberlites in the northeast (Lapido-Loureiro, 1973). Other intrusive carbonatite bodies are found outside this structure, including the Virulundo carbonatite, which is described here (Fig. 1).

\section{The Virulundo carbonatite}

Virulundo mountain is $60 \mathrm{~km}$ south of the town of Virei (in the municipality of the same name), in
Namibe province, about $160 \mathrm{~km}$ southeast of Namibe city (Fig. 1). It is close to the headwaters of the Curoca River, which crosses the Namib Desert in southeast-northwest direction. Access is difficult due to the lack of roads.

Virulundo mountain is a truncated cone, centred at $16^{\circ} 16^{\prime} 34.2^{\prime \prime} \mathrm{S}, 12^{\circ} 55^{\prime} 56.2^{\prime \prime} \mathrm{E}$ (Fig. 2). At $3 \mathrm{~km}$ in diameter, it is one of the largest carbonatite plugs in the world. As the carbonatite is more resistant to erosion than the surrounding granite, Virulundo mountain rises more than $750 \mathrm{~m}$ above the surrounding plain.

Virulundo is a Lower Cretaceous subvolcanic plug intruding Archaean granitoids (Issa Filho et al., 1991), which are fenitized close to the contact with the carbonatites. The fenitization aureole reaches more than $300 \mathrm{~m}$ in width and the resulting rocks can be classified as feldspathic fenites (Le Bas, 2008). The intrusion is zoned and

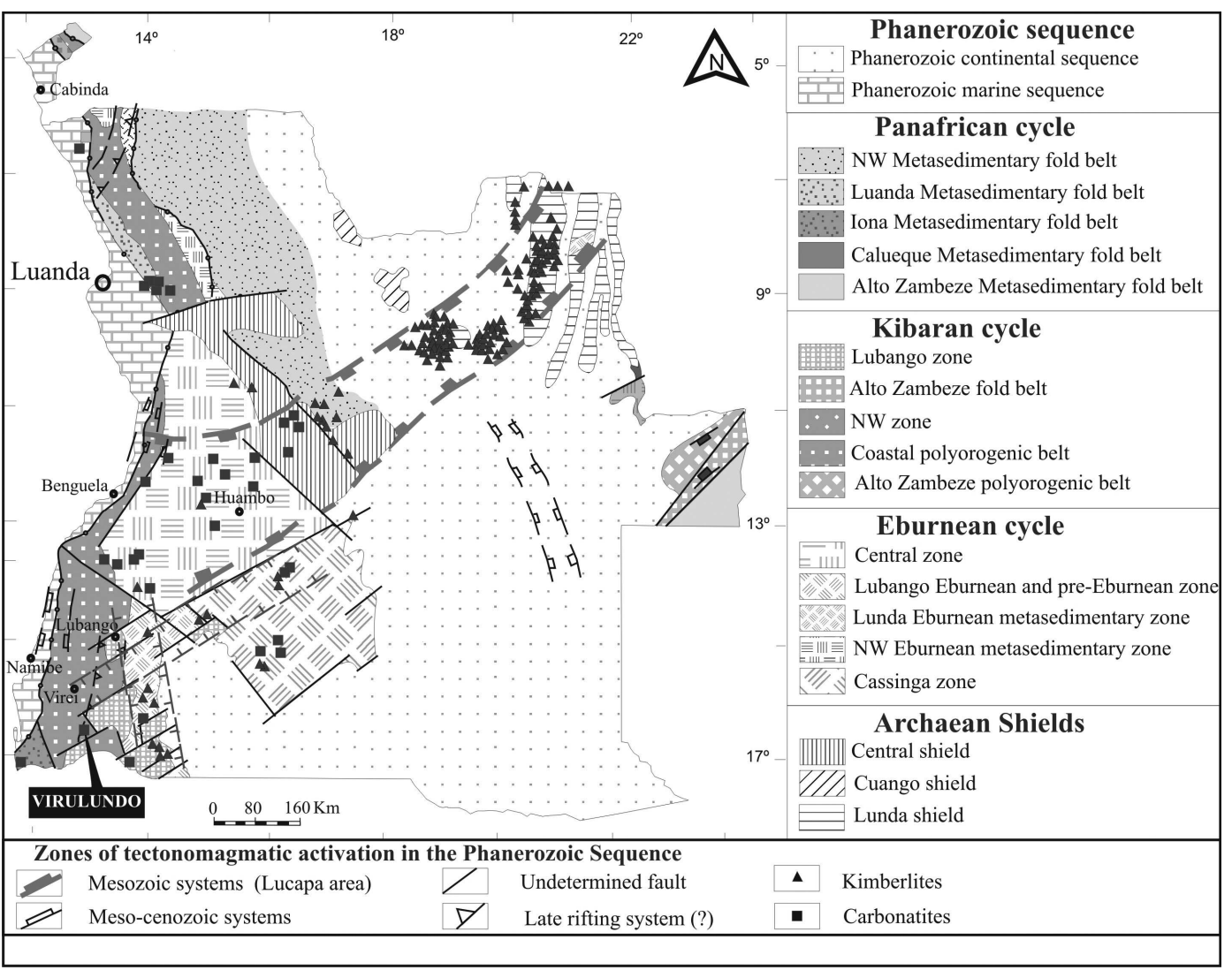

FIG. 1. Geological map of Angola, showing the distribution of carbonatites and kimberlites. Modified after de Carvalho et al. (2000). 


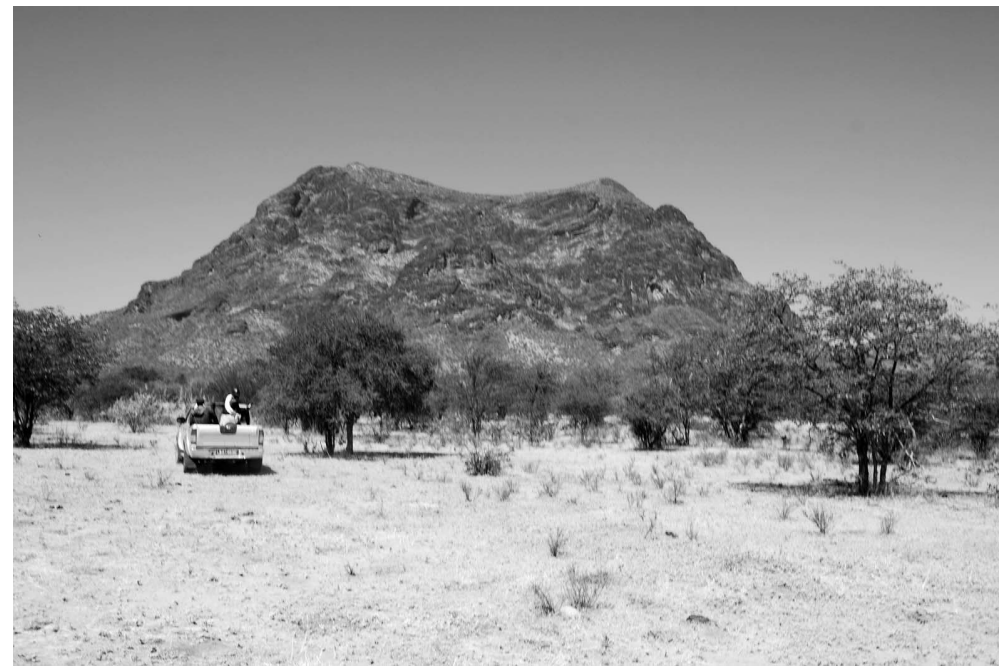

FIG. 2. Panoramic view of Virulundo mountain.

consists of a massive unit at the centre, which is mainly calciocarbonatitic, surrounded by carbonatitic breccias (Fig. 3). The carbonatitic breccias also form ring dykes, a few tens to a few hundred metres in width, which intrude the granites.

The carbonatite breccias consist of fragments of rocks (strongly fenitized granites, ferrocarbonatites and carbonatites) in a carbonatite groundmass. The size of the clasts ranges from a few millimetres to a few tens of metres. They are generally irregular, with rounded surfaces (Fig. 4a). The groundmass is primarily calcite. The ferrocarbonatite fragments are strongly weathered and contain millimetre- to centimetresize subhedral crystals of magnetite.

The carbonatites, fenites and breccias are cut by thin dykes (several millimetres to $<1 \mathrm{~m}$ thick) which are fine-grained and trachytic, and which may correspond to "pseudotrachyte" sensu Le Bas (2008) (Fig. 4b).

The entire assemblage has been strongly affected by late hydrothermal fluids, as shown by the pervasive veining. The veins are randomly oriented and have irregular borders; they range in width from a few micrometres to a few tens of centimetres and contain quartz, baryte, calcite, ankerite and dolomite (Fig. 4c). In the vicinity of the veins, the surrounding carbonatites are partially replaced by these minerals and minor amounts of REE-bearing minerals.

Debris and colluvial sediments are well developed in the area around the plug, and they contain accumulations of heavy minerals including magnetite, pyrochlore, baryte and apatite. Residual and placer deposits containing economically valuable elements are likely to be found in the area.

\section{Mineralogy and textures of the carbonatites}

Calcite and ankerite are the dominant minerals in the Virulundo carbonatites. Fenitized xenocrysts and xenoliths of the granitic host rocks are abundant, particularly in the carbonatite breccia.

Fluorapatite and magnetite are common accessory minerals; phlogopite and zircon are less common. Apatite occurs as euhedral millimetresized prismatic crystals. Magnetite occurs as euhedral octahedral $\{111\}$ crystals, typically $5-10 \mathrm{~mm}$ and rarely $>5 \mathrm{~cm}$ across. These crystals may be concentrated to form much larger aggregates.

Minerals containing rare elements are very abundant in all of the carbonatite units and include pyrochlore and REE silicates, phosphates and carbonates. Pyrochlore crystals range in size from $50 \mu \mathrm{m}$ to $1 \mathrm{~mm}$. They occur in all the carbonatitic units; some millimetre-thick banded units in the calcitic carbonatites are strongly enriched in pyrochlore (Fig. 5a). Four textural varieties of pyrochlore have been identified:

Type 1 pyrochlore is primary and occurs as euhedral octahedral $\{111\}$ crystals that are typically only slightly zoned (Fig. $5 b$ ). Some 


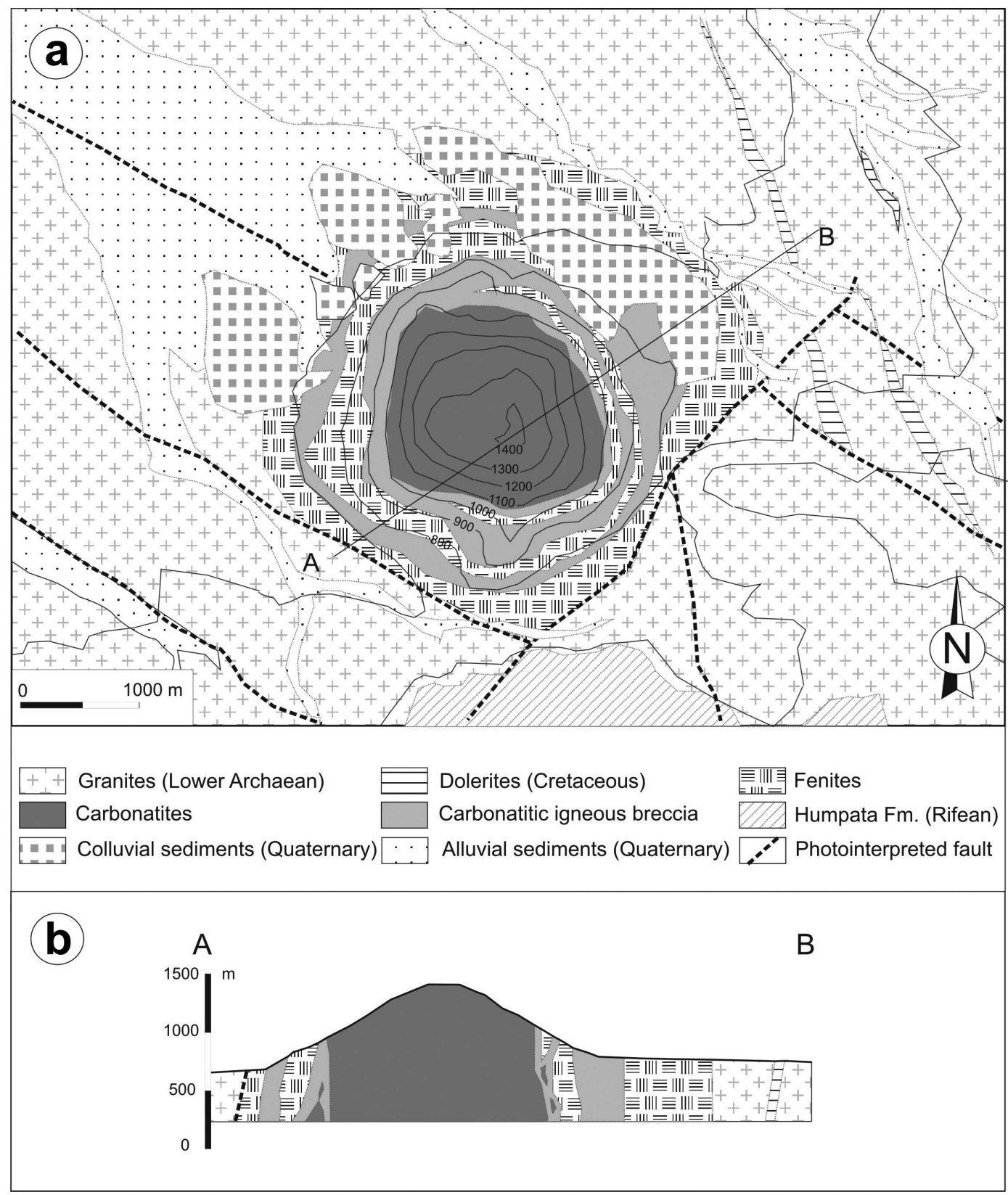

FIG. 3. (a) Geological map of Virulundo mountain; (b) geological section though Virulundo mountain.

crystals, however, have more distinct zonation and occur in complex intergrowths with calcite and apatite. The shape and zoning patterns in these crystals does not depend on the type of carbonatite facies. In some cases, particularly in the carbonatite breccias, the pyrochlore crystals are broken and have angular edges. The contact between these areas and those of type 1 may be sharp or diffuse.

Type 2 pyrochlore occurs as a pseudomorphic replacement product of primary pyrochlore and is found in areas affected by hydrothermal alteration 

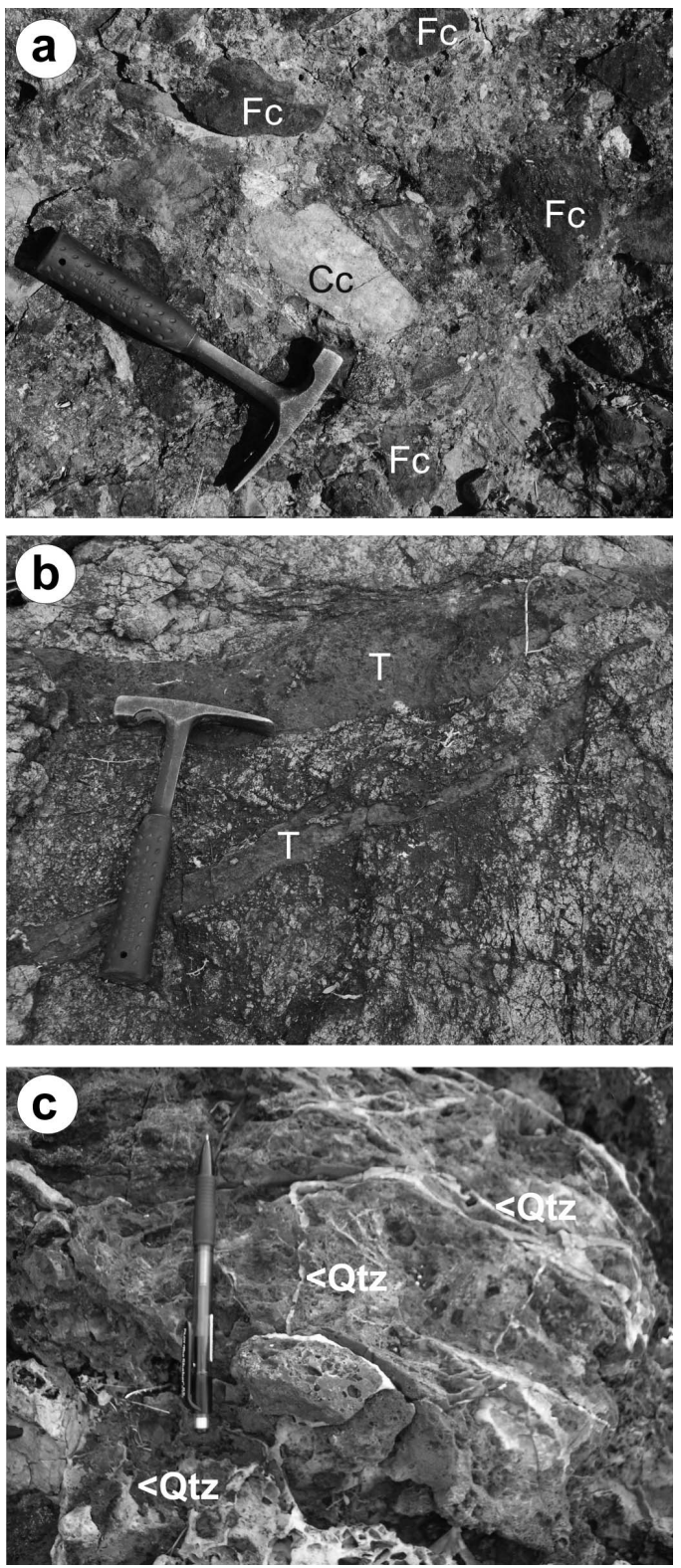

FIG. 4. Field details of the internal structure of the carbonatite. (a) Carbonatite breccias, with dark fragments of ankerite carbonatites (Fc) in a calcite matrix (Cc). (b) Albite trachytic dykes (T) cutting across the carbonatite. (c) Stockwork-like quartz veinlets (qtz) cutting the carbonatite.

(Fig. $5 c$ ). In these cases the primary zoning of the pyrochlore is disrupted by replacement along grain borders or fractures (Fig. 5d). Many primary pyrochlore crystals are completely replaced by second generation pyrochlore.

Type 3 pyrochlore occurs as diffuse patches around small veinlets (Fig. 5e). It is found in the vicinity of hydrothermal veins.

Type 4 pyrochlore occurs in the borders of strongly corroded pyrochlore grains and infills irregular fractures and cracks cutting all previous generations of pyrochlore, often in close association with dissolution porosity, which is partly infilled with small drusy baryte crystals. It is found in areas affected by strong weathering, in close association with supergene minerals including botryoidal aggregates of goethite or hollandite (Fig. 5f). The contact between these areas and those containing type 1 and 2 pyrochlore is diffuse.

Other accessory minerals, including the sulfide minerals pyrite and chalcopyrite, are uncommon. Pyrite occurs rarely as euhedral cubic crystals, less than $1 \mathrm{~mm}$ on edge, which are typically altered to goethite. Chalcopyrite occurs as scattered anhedral grains, less than $0.5 \mathrm{~mm}$ across.

Quartz, calcite, dolomite and ankerite are the dominant minerals in the hydrothermal veins; fluorite, baryte and strontianite are common in some of the veins (Fig. $6 a, b$ ). Druses are common in the veins and consist of euhedral crystals of dolomite, quartz, strontianite and fluorite which do not exceed a few millimetres in size. Fluorite occurs as small anhedral crystals, intergrown with quartz and dolomite or ankerite. Strontianite tends to be euhedral and occurs as pseudohexagonal prismatic twins with oscillatory zoning. Rhabdophane-(Ce) occurs as a late-stage alteration product in some hydrothermal veins, where it replaces strontianite (Fig. 6c). Niobium-rich rutile $\left(\mathrm{Nb}_{2} \mathrm{O}_{5}\right.$ in the range 14.17-18.48 wt.\%) is found as small anhedral crystals, $<50 \mu \mathrm{m}$ in size, in late hydrothermal quartz-calcite veins. Patchy zoning, which is produced by changes in the $\mathrm{Nb}$ content, is apparent in these crystals (Fig. 6d).

Mineral containing $R E E$ s are very abundant in all the carbonatite facies, typically as small crystals, less than $200 \mu \mathrm{m}$ across. They form as a result of hydrothermal or weathering processes, tend to be euhedral, commonly infill porous areas in the rocks, and are found in the carbonatites and the surrounding fenitized rocks (Fig. 7a). Most of the $R E E$-bearing carbonates and silicates are associated with supergene minerals such as goethite or hollandite (Fig. $7 a-d$ ). Although hollandite-type minerals are found in the 
L. TORRÓ ET AL.
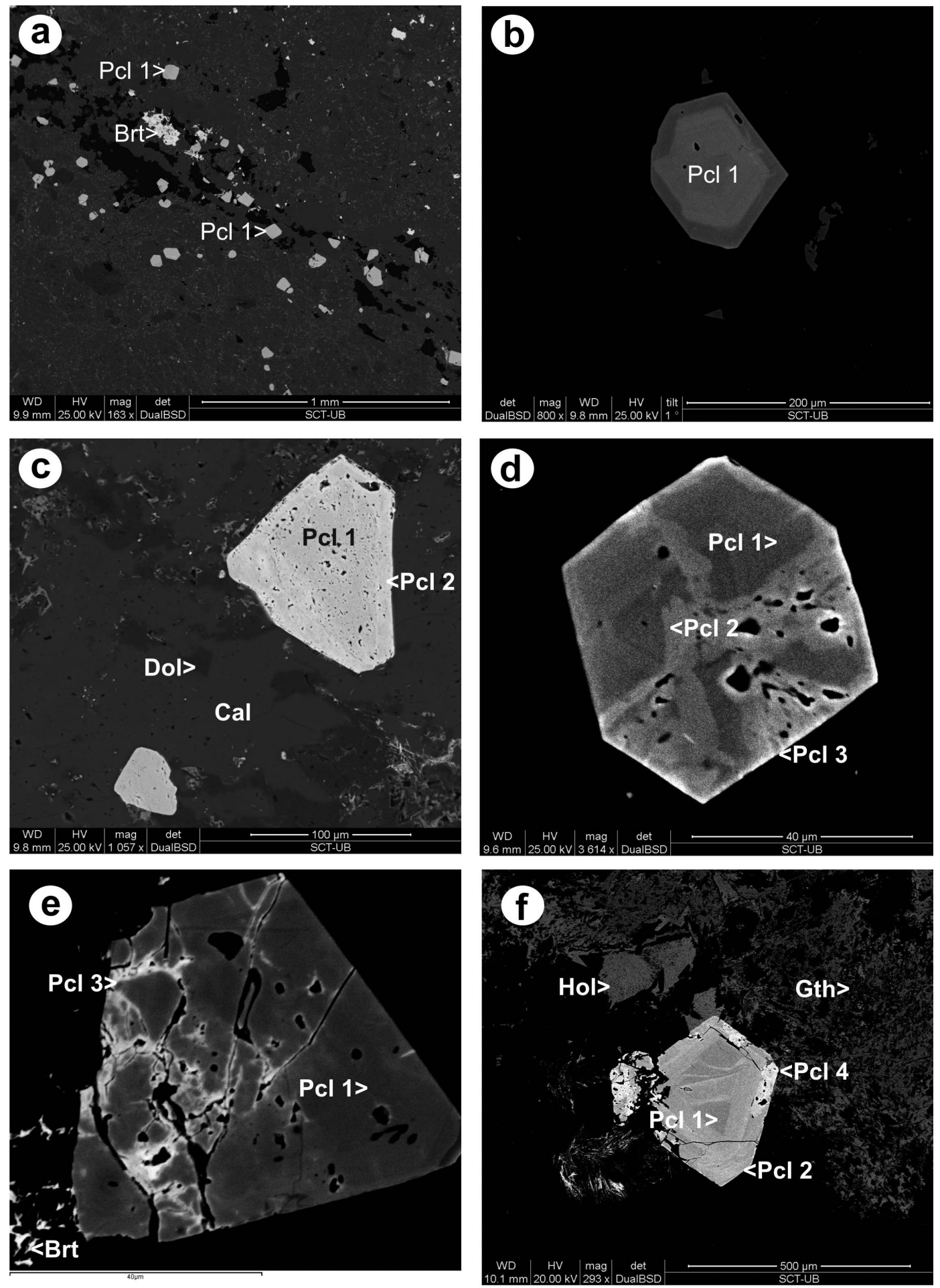

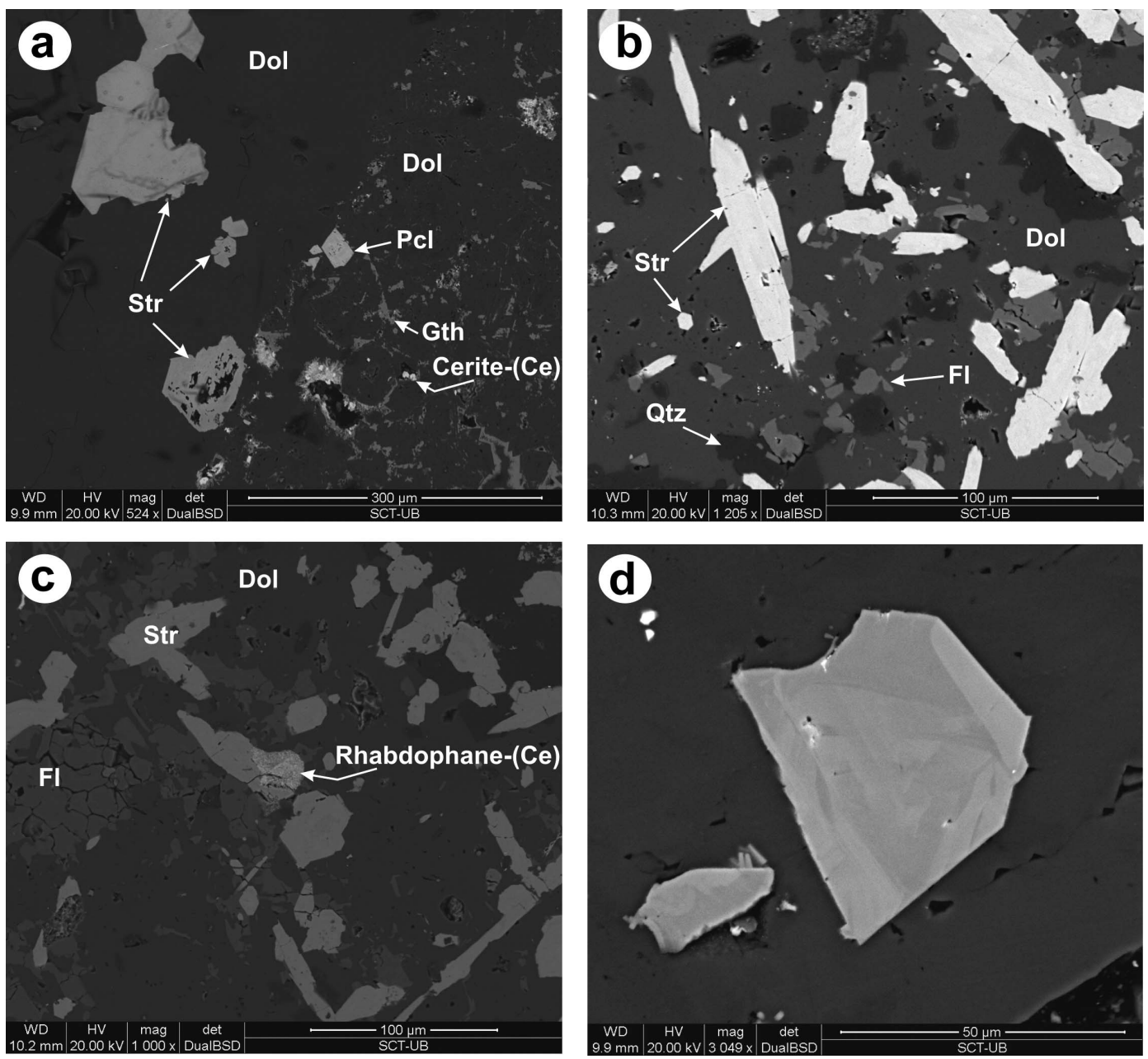

FIG. 6. Textural patterns of the hydrothermal vein infilling. (a) Vein infilled with dolomite (Dol) and strontianite (Str) cutting a carbonatite (righthand side of the image). The carbonatite is strongly replaced by hydrothermal dolomite (Dol) close to the vein contact and has secondary Sr-rich pyrochlore $(\mathrm{Pcl})$. Supergene processes have produced goethite (Gth) and cerite-(Ce). (b) Mineral associations in the hydrothermal veins including fluorite (Fl), quartz (Qtz), dolomite (Dol) and strontianite (Str). (c) Mineral associations in the hydrothermal veins: strontianite is replaced by late-stage rhabdophane-(Ce). (d) Niobium-rich rutile with complex internal zoning. Scanning electron microscope images in BSE mode. Abbreviations are after Whitney and Evans (2010).

FIG. 5 (facing page). Textural patterns of the different pyrochlore generations. (a) Euhedral primary pyrochlore crystals forming bands in carbonatite. (b) Zoned primary magmatic pyrochlore crystal ( $\mathrm{Pcl}$ 1). (c) Calcitic carbonatite $(\mathrm{Cal})$ replaced by hydrothermal dolomite (Dol); pyrochlore is replaced by secondary pyrochlore along grain boundaries. $(d)$ Detail of a primary pyrochlore crystal $(\mathrm{Pcl} 1)$ with zoning disrupted by secondary pyrochlore ( $\mathrm{Pcl}$ 2). (e) Pyrochlore of the first generation ( $\mathrm{Pcl} 1$ ) replaced along cracks by pyrochlore of the third generation (Pcl 3). Baryte $(\mathrm{Ba})$ is also present. $(f)$ Pyrochlore crystal from a strongly weathered carbonatite. Primary pyrochlore (Pcl $1)$ is replaced by a second generation of pyrochlore $(\mathrm{Pcl} 2)$ and both are replaced by a fourth generation ( $\mathrm{Pcl} 4)$. Note the occurrence of goethite (Gth) and hollandite (Hol). Scanning electron microscope images in BSE mode.

Abbreviations are after Whitney and Evans (2010). 

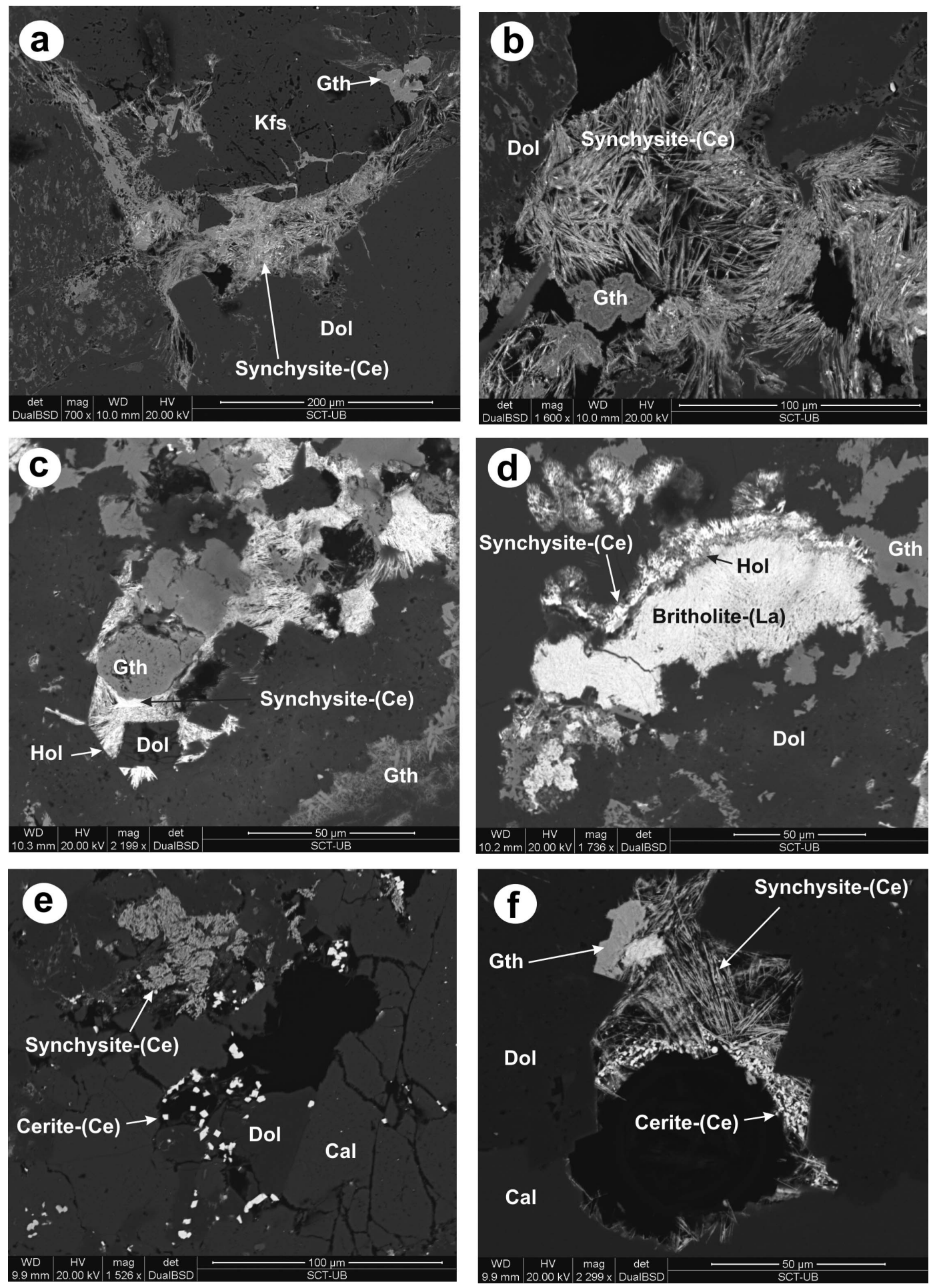
primary magmatic assemblage at the Schryburt Lake carbonatite complex in Ontario (Platt, 1994), Virulundo hollandite commonly fills porous areas in the rock which are generated by supergene alteration and weathering processes. It occurs as botryoidal aggregates in a similar manner to goethite, and both minerals are clearly supergene in origin. Baryte is common in these associations as small platelets or radiating crystal aggregates. The REE-bearing minerals are synchysite-(Ce), britholite-(Ce), britholite-(La) and cerite-(Ce). Synchysite-(Ce) is the most abundant REE mineral at Virulundo, it occurs as euhedral tabular crystals, usually in radiating aggregates (Fig. $7 a-d$ ). Britholite-(Ce) and britholite-(La) occur as needle-like crystals arranged in radiating or botryoidal aggregates (Fig. 7d), and also occur as anhedral grains. Britholite-(Ce) and britholite-(La) occur as separate grains. Cerite-(Ce) is the last mineral to be formed in the cavities and occurs as small euhedral rhombohedral crystals, $<10 \mu \mathrm{m}$ across (Fig. $7 d$ ).

\section{Analytical methods}

The pyrochlore paragenesis and textures were studied by scanning electron microscopy (SEM) in back-scattered electron (BSE) imaging mode using polished thin-sections. The BSE images, which show atomic number contrast, were used to select points for analysis by energy dispersive X-ray spectrometry (EDS). The EDS analyses were performed at the Serveis Científico-Tècnics, Universitat de Barcelona on a Quanta Q-200 (FEI Company) scanning electron microscope, equipped with a Genesis (EDAX) energy dispersive X-ray spectrometry microanalysis system, and on a Cambridge Instruments Stereoscan 360 scanning electron microscope equipped with an INCA ENERGY 200 microanalysis system. Operating conditions were $30 \mathrm{kV}$ and $1 \mathrm{nA}$ beam current and $20-25 \mathrm{~mm}$ distance from sample to detector.
Quantitative major-element analyses were made on an electron microprobe (EPMA) using wavelength-dispersive spectrometry (WDS) at the Serveis Científico-Tècnics of the Universitat de Barcelona and at the Natural History Museum in London. Wavelength dispersive analyses on a Cameca SX50 electron microprobe used the PAP matrix correction programme (Pichou and Pichoir, 1984). To minimize devolatilization, an accelerating voltage of $15-20 \mathrm{kV}$ was combined with a beam current of 5-20 nA and a $10-15 \mu \mathrm{m}$ beam diameter. Standards and lines used for the analyses were as follows: fluorite $(\mathrm{FK} \alpha)$; albite $(\mathrm{NaKa})$; periclase $(\mathrm{MgK} \alpha)$; synthetic $\mathrm{Al}_{2} \mathrm{O}_{3}(\mathrm{Al} K \alpha)$; diopside $(\mathrm{Si} K \mathrm{a})$; orthoclase $(\mathrm{K} K \alpha)$; wollastonite $(\mathrm{Ca} K \alpha)$; rutile $(\mathrm{Ti} K \alpha)$; rhodonite $(\mathrm{Mn} K \alpha) ; \mathrm{Fe}_{2} \mathrm{O}_{3}$ $(\mathrm{Fe} K \alpha)$; celestine $(\mathrm{Sr} L \mathrm{a})$; YAG $(\mathrm{Y} L \alpha) ; \mathrm{ZrO}$ $(\mathrm{Zr} L \alpha) ; \mathrm{Nb}(\mathrm{Nb} L \alpha) ; \operatorname{SnO}(\operatorname{Sn} L \alpha)$; baryte $(\mathrm{Ba} L \alpha)$; $\mathrm{LaB}_{6}(\mathrm{La} L \alpha) ; \mathrm{CeO}_{2}(\mathrm{Ce} L \alpha) ;$ REE1 $(\operatorname{Pr} L \beta) ;$ REE4 $(\mathrm{Nd} L \alpha) ; R E E 3$ (SmLa); Ta $(\mathrm{Ta} M \alpha)$; W (WM $\alpha)$; $\mathrm{PbS}(\mathrm{Pb} M \alpha) ; \mathrm{ThO}_{2}(\mathrm{Th} M \alpha) ; \mathrm{UO}_{2}(\mathrm{U} M \alpha)$.

\section{Composition of pyrochlore}

The general formula for pyrochlore-group minerals can be written $A_{2-m} B_{2} X_{6-w} Y_{1-n}$, where $A=\mathrm{Na}$, $\mathrm{Ca}, \mathrm{Mn}, \mathrm{Fe}^{2+}, \mathrm{Sc}, \mathrm{Sn}, \mathrm{Sr}, \mathrm{Sb}, \mathrm{Cs}, \mathrm{Ba}, \mathrm{REE}, \mathrm{Pb}, \mathrm{Bi}$, Th and $\mathrm{U} ; B=\mathrm{Nb}, \mathrm{Ta}, \mathrm{Ti}, \mathrm{Al}, \mathrm{Fe}^{3+}, \mathrm{Zr}$, Sn and $\mathrm{W}$; $X=\mathrm{O}, \mathrm{OH}$; and $Y=\mathrm{O}, \mathrm{OH}$, and $\mathrm{F}$ (Atencio et al., 2010). Calculations of the structural formulae of the pyrochlores were made on the basis of 2 a.p.f.u. (atoms per formula unit) at the $B$ site and assuming all $\mathrm{Fe}$ as $\mathrm{Fe}^{3+}$. This can produce errors in the analysis of supergene pyrochlores: Nasraoui and Waerenborgh (2001) found $\sim 47 \% \mathrm{Fe}^{2+}$ in secondary pyrochlore from the Lueshe mine in Congo. However, the total amount of iron, $\mathrm{Fe}_{t}$, in the pyrochlores from the Virulundo carbonatites is very low, and hence the error is likely to be small.

The pyrochlore analyses were separated according to the type of host rock and the generation. Representative compositions are listed in Table 1. All the analysed pyrochlore

Fig. 7 (facing page). Textural patterns of the supergene REE minerals. (a) Euhedral tabular synchysite-(Ce) and dolomite (Dol) filling porous areas in fenitized rock, with K-feldspar fragments (Kfs). (b) Detail of synchysite-(Ce) platelets filling porous areas in hydrothermal dolomite druses (Dol). Note the association of synchysite-(Ce) with botryoidal goethite (Gth). (c) Crystallization sequence in a porous area in a dolomite druse (Dol). Botryoidal goethite aggregates (Gth) are overgrown by synchysite-Ce and later hollandite (Hol). (d) Detail of an infilling, with dolomite rhombohedrons overgrown by britholite-(La), hollandite (Hol), synchysite-(Ce) and goethite (Gth). (e) Euhedral cerite-(Ce) rhombohedrons infilling cavities in dolomitized carbonatite. $(f)$ Paragenetic sequence of a late-stage infilling. Note that synchysite-(Ce) encrusts goethite (Gth) and is overgrown by cerite-(Ce). Scanning electron microscope images in BSE mode. Abbreviations are after Whitney and Evans (2010). 


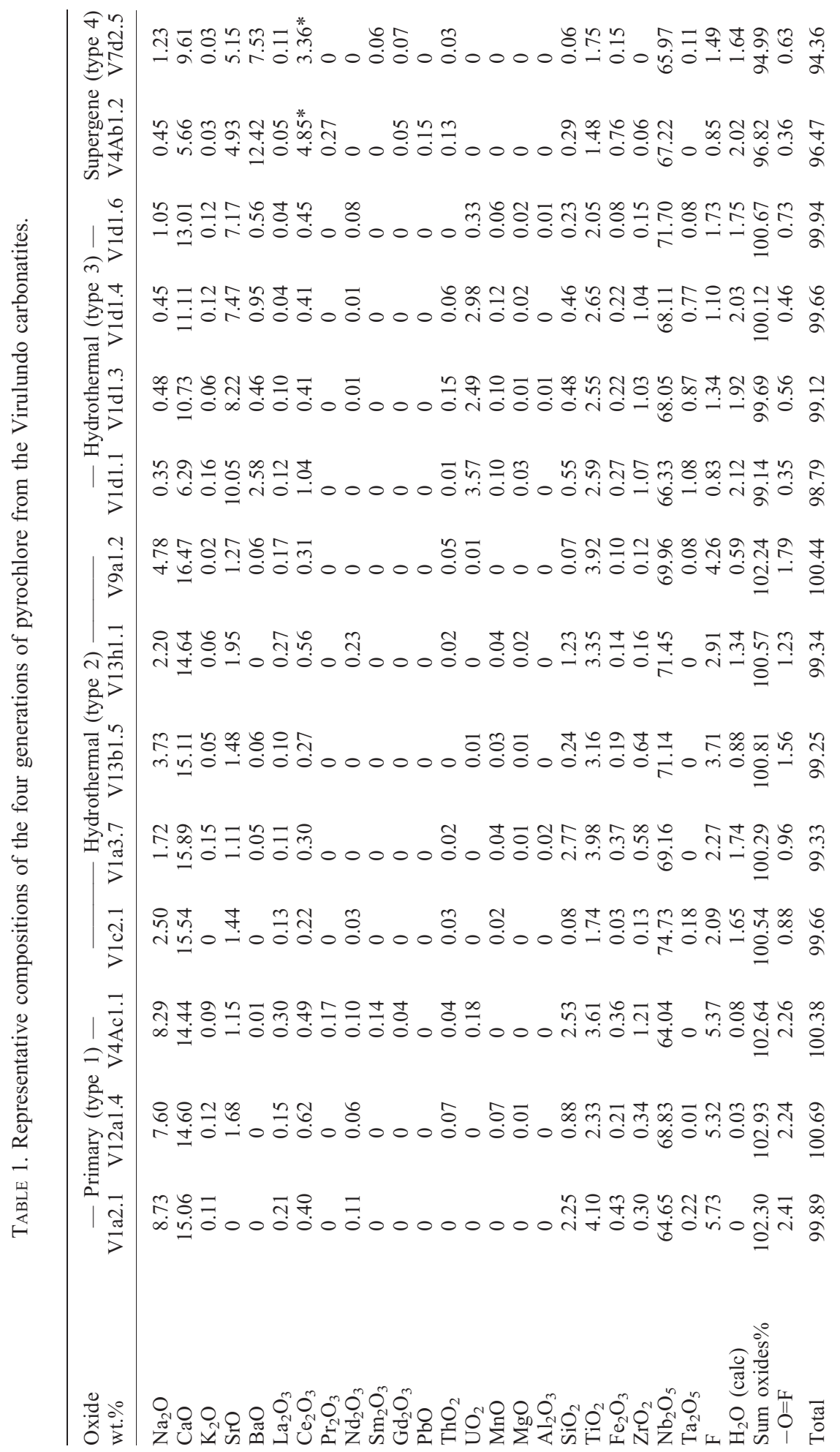




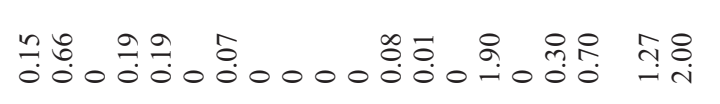

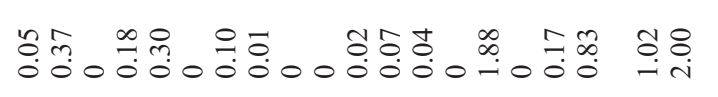

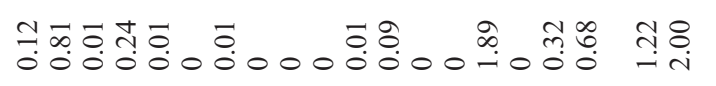

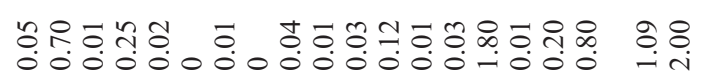

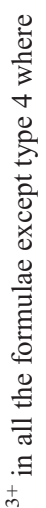

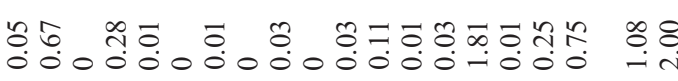

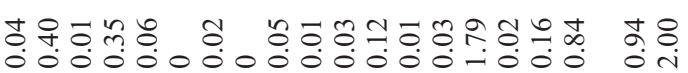

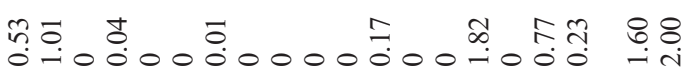

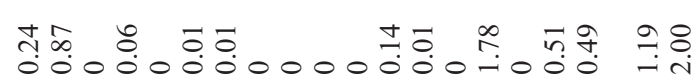

नं

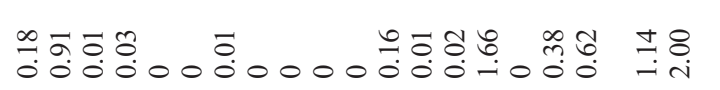

तู่

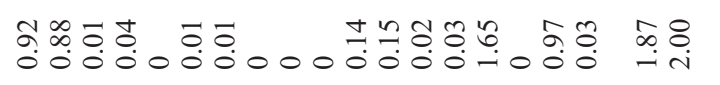

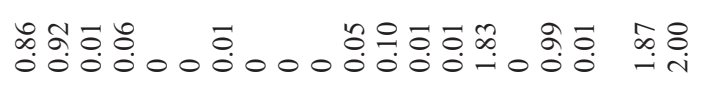

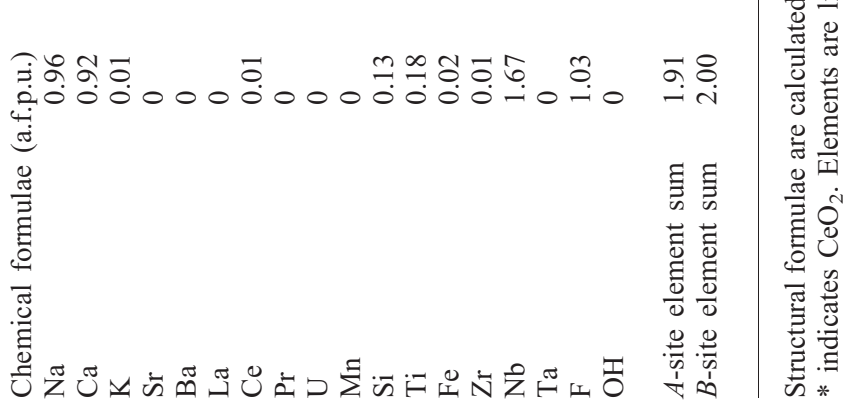


crystals are $\mathrm{Nb}$-rich, with very low $\mathrm{Ta}$ and $\mathrm{Ti}$ contents (Fig. 8). The $\mathrm{Zr}$ and Si contents are also very low.

In the type 1 primary magmatic pyrochlore, $\mathrm{F}$ is dominant at the $Y$ site, which typically contains close to 1 a.p.f.u. The $A$ site is dominated by $\mathrm{Na}$ and $\mathrm{Ca}$; other elements and vacancies are minor. Using the classification of Atencio et al. (2010), the primary pyrochlore crystals from Virulundo lie near to the compositional boundary between fluorcalciopyrochlore and fluornatropyrochlore. In most cases calcium is the dominant substituent at the $A$ site and these are sodium-rich fluorcalciopyrochlore, but in some cases sodium is dominant and these are calcium-rich fluornatropyrochlore (see composition data in Table 1). These compositions are typical of those reported from carbonatites and fenites worldwide (Yaroshevskii and Bagdasarov, 2008). There are no significant differences in the compositions of primary pyrochlore from the calciocarbonatites and ferrocarbonatites. Zonation is mostly related to minor compositional changes at the $B$ site. In particular, the $\mathrm{Ti} / \mathrm{Nb}$ ratio, which produces a slight decrease in $\mathrm{Na}$ at the $A$ site, accompanied by a coupled increase in Th and/or REEs.

During hydrothermal and supergene alteration processes, there are major chemical changes at the $A$ site, but the $B$ site elements remain relatively unaffected. The changes in pyrochlore composition consist of a progressive decrease in the $\mathrm{Na}$ and $\mathrm{Ca}$ content at the $A$ site coupled with an increase in the number of vacancies. Three successive alteration trends can be distinguished:

The first trend (trend 1, Fig. 9) produces type 2 pyrochlores, and is characterized by a reduction in the amount of $\mathrm{Na}$ at the $A$ site, with $\mathrm{Ca}$ remaining constant. The $\mathrm{F}$ content decreases during the alteration process in similar molar proportions to $\mathrm{Na}$; the coupled substitution $\mathrm{Na}^{+}+\mathrm{F}^{-} \leftrightarrow{ }^{A} \square+$ ${ }^{Y} \square$, where the symbols on the right hand side of the equation represent $A$ - and $Y$-site vacancies, maintains charge balance. The $\mathrm{Na}$ and $\mathrm{F}$ contents of type 2 pyrochlores are progressively reduced

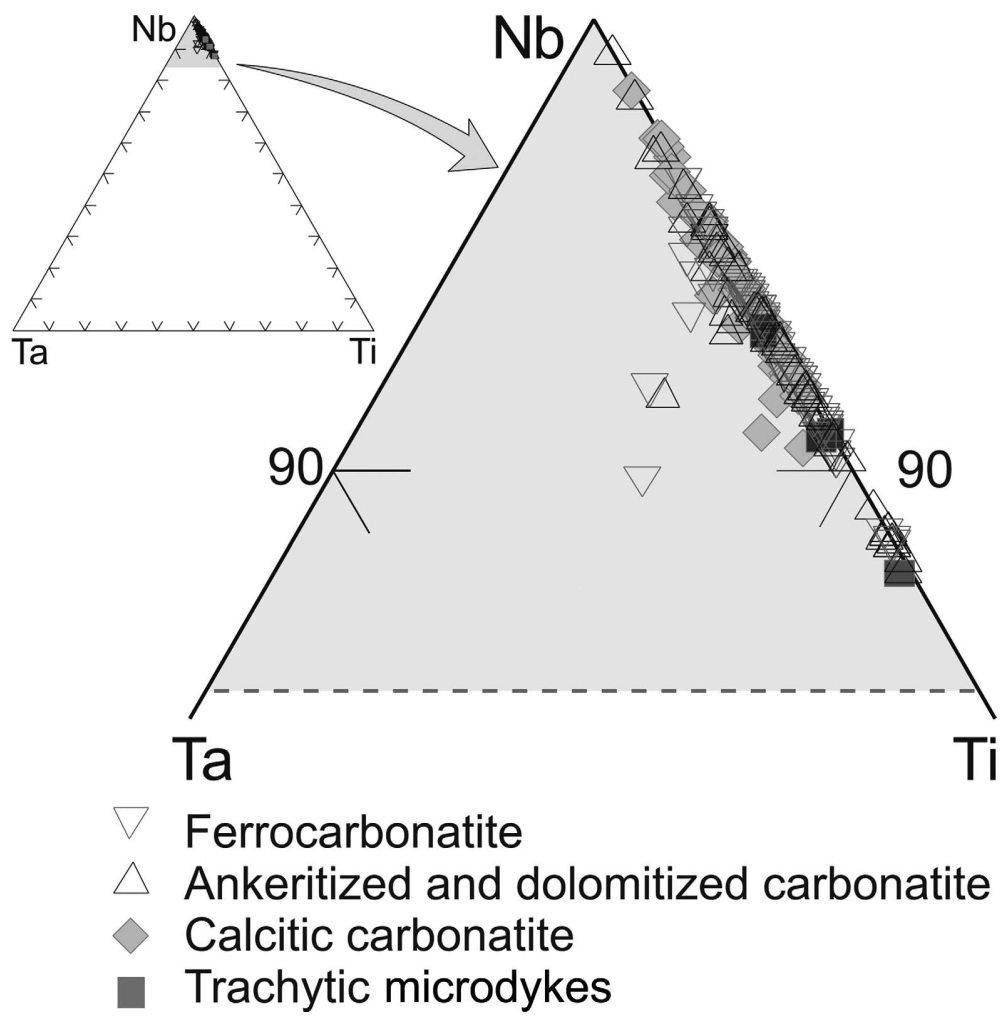

FIG. 8. The compositions of pyrochlore from the Virulundo carbonatites plotted on the apical section of a $\mathrm{Nb}-\mathrm{Ta}-\mathrm{Ti}$ ternary diagram (Hogarth, 1977). 


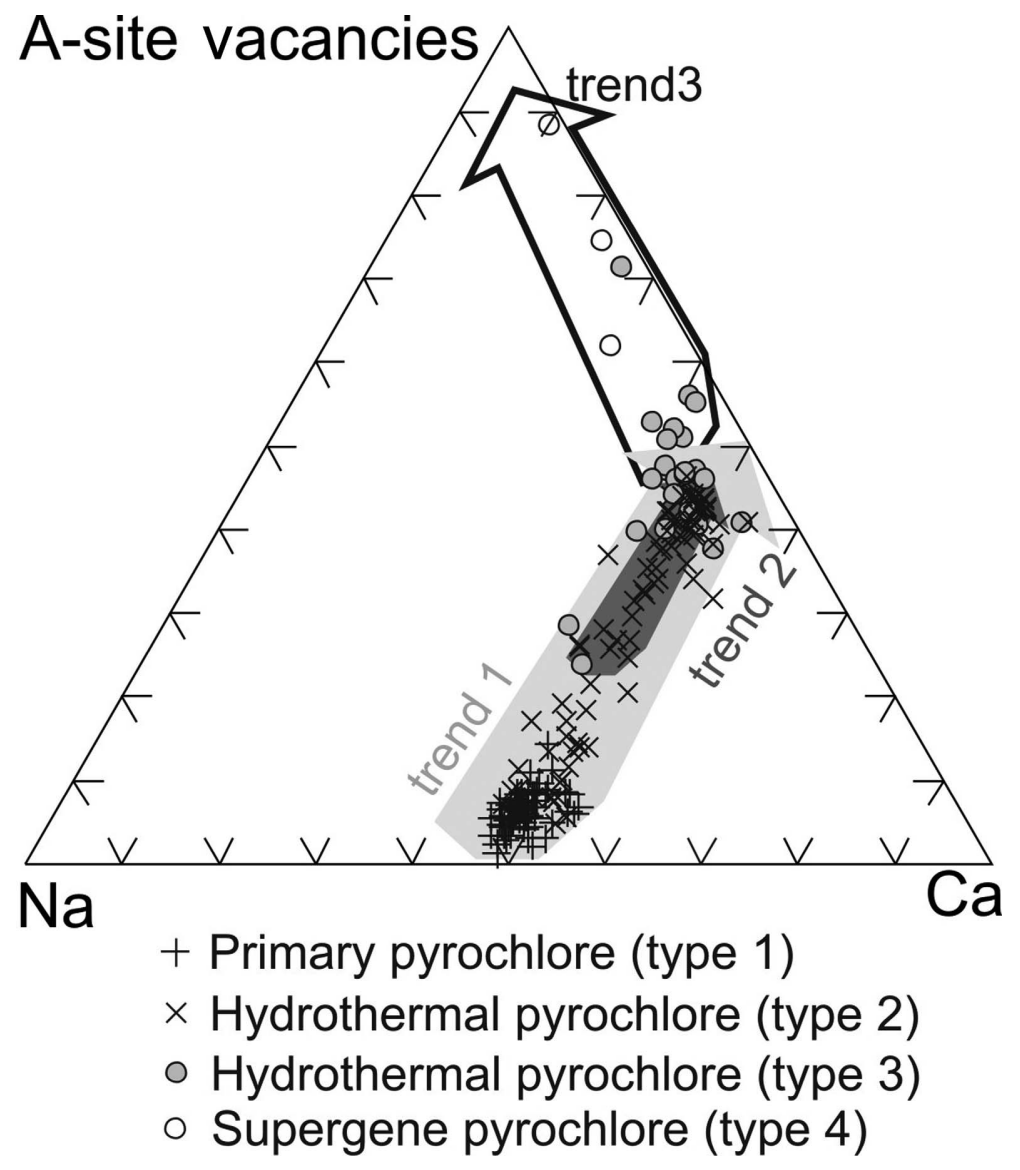

FIG. 9. The compositions of pyrochlore from the Virulundo carbonatites plotted on a $\mathrm{Na}-\mathrm{Ca}-\mathrm{A}$-site-vacancies ternary diagram (Williams et al., 1997).

by this type of substitution to 0.2 a.p.f.u. Type 2 pyrochlore crystals are not significantly enriched in other elements at the $A$ site, although Th is present at up to 0.04 a.p.f.u. in some crystals.

A second trend is characterized by enrichment in $\mathrm{Sr}$ (up to 0.36 a.p.f.u.) with a constant $\mathrm{Ca}$ content, to produce type 3 pyrochlore. The REE and high field strength element (HFSE) content at the $A$ site are generally less than 0.01 a.p.f.u., although some pyrochlore crystals are enriched in $\mathrm{U}$ (at up to 0.05 a.p.f.u.). Similar patterns of hydrothermal alteration were described at Lueshe mine in Congo by Nasraoui et al. (1999) and Nasraoui and Bilal (2000).

A third trend produces type 4 pyrochlores, which are highly enriched in $\mathrm{Ba}$ (up to 0.37 a.p.f.u.), have reduced $\mathrm{Ca}$ contents, and a high vacancy content. Barium and strontium do not reach 1 a.p.f.u. in the structural formulae, and the number of vacancies at the $A$ site approaches 1 a.p.f.u., producing compositions that can be described as kenohydroxypyrochlore in the nomenclature of Atencio et al. (2010). However, the classification of Hogarth (1977) is more useful in describing the pyrochlore compositions. As $\mathrm{Ba}$ and $\mathrm{Sr}$ are the dominant cations at the $A$ site, in this classification these pyrochlore grains can be described as 'strontiopyrochlore' and 'bariopyrochlore'. The type 4 pyrochlores are systematically enriched in Ce, with up to 0.13 a.p.f.u., but do not contain other REEs.

\section{Discussion}

The structure of the Virulundo carbonatite has many similarities with those of other carbonatite 
intrusions in Angola and Namibia (e.g. Cooper and Read, 2000). The occurrence of broken crystals of pyrochlore in the carbonatite breccias suggests that most primary pyrochlore crystallization took place before the explosive phenomena that produced the late carbonatite breccias. However, some pyrochlore is also found in the carbonatite matrix of these breccias, indicating that pyrochlore also crystallized at a later stage.

Fluorine-rich pyrochlore-group minerals are the dominant phases in carbonatites worldwide, probably because the F content of the carbonatite magma is the key to the crystallization of pyrochlores rather than perovskite-group minerals (Jago and Gittins, 1991, 1993; Mitchell and Kjarsgaard, 2004). The compositions of the primary pyrochlores at Virulundo are relatively constant. The Ta contents are particularly low when compared with other carbonatites worldwide (e.g. Hogarth et al., 2000; Lee et al., 2006). However, major Ta enrichment is rare in carbonatites (Bagdasarov, 2009). Oscillatory zoning in the primary pyrochlore may reflect supersaturation in $\mathrm{Nb}, \mathrm{Ti}$ and $\mathrm{Th}$ in the carbonatite melt (Hogarth et al., 2000). On the other hand, changes in the proportions of HFSE in the $A$ and $B$ sites, coupled with changes in the F content may be important (see Bambi et al., 2012).

Subsolidus processes are responsible of many changes in the $A$-site composition of pyrochlores, whereas the $B$ site remains relatively unaffected (Lumpkin and Ewing, 1995; Lumpkin and Mariano, 1996). Lumpkin and Ewing (1995) noted that $\mathrm{F}$ and $\mathrm{Na}$ are lost during subsolidus processes, and the number of vacancies in the $A$ and $Y$ sites increases accordingly. Extreme leaching of $A$-site cations can produce a relative enrichment in $\mathrm{K}$, producing 'kalipyrochlore' (Ercit et al., 1994). During hydrothermal processes the Na content of pyrochlore decreases and $\mathrm{Ca}$ remains constant in the first stage but in the supergene alteration processes $\mathrm{Ca}$ is also removed (Williams et al., 1997). Strong enrichments in $\mathrm{Ce}, \mathrm{Ba}$ and $\mathrm{Sr}$, as observed at Virulundo at the $A$ site in the pyrochlore structure are common in many carbonatites worldwide; the mechanism of this enrichment process is controversial. Chakhmouradian and Mitchell (1998) found high $\mathrm{Sr}$ contents (up to 43 wt.\% $\mathrm{SrO}$ ) and Ba contents ( $8-18$ wt. $\% \mathrm{BaO}$ ) in pyrochlore from the carbonatites of the Lesnaya Varaka complex, Russia. They suggested that these were the result of hydrothermal alteration. However, similar compositions have been reported in weathered pyrochlore from laterites worldwide. Some examples include the Mt. Weld carbonatite in Western Australia (Lottermoser and England, 1988), the Mabounié carbonatite in Gabon (Laval et al., 1988), the Bingo carbonatite in Uganda (Williams et al., 1997), the Lueshe carbonatite in Congo (Nasraoui et al., 1999; Nasraoui and Bilal, 2000) and the Catalão II carbonatitic deposit in Brazil (Rocha et al., 2001). In all these cases the $A$-site element content is dependent on the position of the pyrochlore in the lateritic profile. At Lueshe, moreover, $\mathrm{Ba}$ - and $\mathrm{Sr}-$ bearing pyrochlore is found in association with supergene minerals (Wall et al., 1996). Geisler et al. (2004) carried out hydrothermal experiments to determine the changes in the composition of microlite in neutral and acid solutions at $175^{\circ} \mathrm{C}$. These experiments showed that $A$-site cations and $\mathrm{F}$ are easily removed from the pyrochlore structure, producing chemical alteration trends and textures that are identical to those described from Virulundo and at other localities worldwide.

At Virulundo, hydrothermal alteration may have been a relatively continuous process, because there is evidence of high-temperature hydrothermal processes (magmatic and hydrothermal brecciation and fenitization) and lowtemperature processes (the formation of quartz veins with fluorite, calcite, dolomite, ankerite and strontianite). Therefore, some of the intense replacement textures could have been produced at high temperatures, as suggested by Lumpkin and Ewing (1995). At these temperatures $\mathrm{Sr}$ is locked up in the magmatic carbonates, and as a result in the first stage of hydrothermal alteration $\mathrm{Sr}$ is not incorporated in the pyrochlore structure. The first compositional trend and the formation of type 2 pyrochlore can be explained as a hightemperature replacement process.

During the low-temperature hydrothermal processes that produced the quartz-carbonatefluorite veins, several generations of hydrothermal carbonates replace the original magmatic carbonates in the carbonatite. Low-temperature hydrothermal carbonates are unable to accommodate large cations such as $\mathrm{Sr}$ and $\mathrm{Ba}$ in their structures. As a result, these elements preferentially partition into the hydrothermal fluid, which explains the occurrence of vein strontianite, and the formation of Sr-rich secondary type 3 pyrochlore.

The supergene oxidation of the primary carbonatitic sulfides may have produced the $\mathrm{SO}_{4}^{2-}$ anions required for the precipitation of 
baryte. Supergene carbonates and the botryoidal $\mathrm{Fe}-$ and Mn- oxides were also formed at this stage. Rare earth elements released by the alteration of primary carbonates produced $R E E$-bearing supergene fluids, which deposited the late-stage $R E E$ minerals. The formation of distinct Ce-bearing minerals, and the separation of this element from the rest of REEs, is probably due to the formation of $\mathrm{Ce}^{4+}$ in these oxidising environments (Waber, 1992). This oxidation process is also probably responsible for the incorporation of $\mathrm{Ce}$ in the Ba-rich pyrochlore. Therefore, at Virulundo, Ba-rich pyrochlore was also probably produced in a supergene environment, as at other carbonatites worldwide (Nasraui et al., 1999; Rocha et al., 2001).

\section{Conclusions}

Four stages can be identified in the mineralization at Virulundo:

(1) In the early magmatic stage of carbonatite formation, fluorine-rich pyrochlore formed, initially as a liquidus phase in euhedral crystals; at a later stage it co-crystallized with apatite and calcite. The primary pyrochlore is weakly zoned and the zonation is related to slight changes in the Ti content at the $B$ site and slight changes in the U-Th content at the $A$ site. The Ta content is very low. The composition of the primary pyrochlore is almost constant in all the carbonatites at Virulundo (calciocarbonatites, ferrocarbonatites, carbonatite breccias, trachytoids). At the magmatic stage of carbonatite formation, $R E E$ and $\mathrm{Sr}$ were incorporated as minor elements in the structures of the primary magmatic carbonates; no discrete $\mathrm{Sr}-$ or $R E E$-bearing phases crystallized.

(2) In later high-temperature hydrothermal processes, the pyrochlore crystals were partly to completely pseudomorphed by a second generation of pyrochlore with depletion of $\mathrm{Na}$ at the $A$ site and coupled loss of $\mathrm{F}$ at the $Y$ site. The $B$ site composition remained stable.

(3) At a late stage of crystallization, the carbonatite was invaded by lower temperature hydrothermal fluids which produced a strong and extensive silicification and a secondary generation of carbonates and fluorite. Strontium-rich pyrochlore 'strontiopyrochlore' (sensu Hogarth, 1977) crystallized at this stage as veinlets cutting across earlier pyrochlore crystals. There are no changes in the $B$-site composition of this phase.

(4) Supergene alteration of the primary carbonates produced fluids rich in REEs, which precipitated synchysite-(Ce), cerite-(Ce) and britholite, in association with baryte, hollandite and goethite. At this stage, Ba-rich pyrochlore formed in veinlets or along grain boundaries, replacing all the earlier generations of pyrochlore. Supergene pyrochlore is depleted in $\mathrm{Na}, \mathrm{F}$ and $\mathrm{Ca}$, and the resultant increase in vacancies at the $A$ and $Y$ sites is only partly offset by the presence of $\mathrm{Ba}, \mathrm{Sr}$ and $\mathrm{Ce}^{4+}$. The content of the $B$ site remains constant.

The high pyrochlore content of the Virulundo carbonatite means that minerals containing economically valuable elements are likely to be concentrated in alluvial sediments in the surrounding areas.

\section{Acknowledgements}

This research was supported by the projects CGL2006-12973 and CGL2009-13758 (Ministerio de Educación y Ciencia de España) and SGR 589 and SGR 444 (Generalitat de Catalunya). Logistic assistance for the field trips was provided by the Departmento de Geologia da Universidade Agostinho Neto (Luanda, Angola). Dr Xavier Llovet assisted in the preparation of EPMA analyses at the Serveis Científico-Tècnics, Universitat de Barcelona. Alan F. Cooper and another anonymous reviewer improved the early version of this manuscript; Hilary Downes kindly improved the English usage in the reviewed manuscript.

\section{References}

Alberti, A., Castorina, F., Censi, P., Comin-Chiaramoni, P. and de Barros Gomes, C. (1999) Geochemical characteristics of Cretaceous carbonatites from Angola. Journal of African Earth Sciences, 29, 735-759.

Aral, H. and Bruckard, W.J. (2008) Characterisation of the Mt. Weld (Western Australia) niobium ore. Transactions of the Institutions of Mining and Metallurgy, Section C: Mineral Processing and Extractive Metallurgy, 117, 193-204.

Atencio, D., Andrade, M.B., Christy, A.G., Gieré, R. and Kartashov, P.M. (2010) The pyrochlore supergroup of minerals: nomenclature. The Canadian Mineralogist, 48, 673-698.

Bagdasarov, Y.A. (2009) On the geochemistry of tantalum in the carbonatite process. Geochemistry International, 47, 163-173.

Bambi, A.C.J.M, Costanzo, A., Gonçalves, A.O. and Melgarejo, J.C. (2012) Tracing the chemical evolution of primary pyrochlore from plutonic to 
volcanic carbonatites: the role of fluorine. Mineralogical Magazine 76, 377-392.

Castorina, F., Censi, P., Barbieri, M., CominChiaramonti, P., Cundari, A., de Barros Gomes, C. and Pardini, G. (1996) Carbonatites from eastern Paraguay: a comparison with coeval carbonatites from Brazil and Angola. Pp. 231-248 in: Alkaline magmatism in central-eastern Paraguay; relationships with coeval magmatism in Brazil (P. CominChiaramonti and C.B. de Barros Gomes, editors). Editora da Universidade de São Paulo, São Paulo, Brazil, 464 pp.

Chakhmouradian, A.R. and Mitchell, R.H. (1998) Lueshite, pyrochlore and monazite-(Ce) from apatite-dolomite carbonatite, Lesnaya Varaka complex, Kola Peninsula, Russia. Mineralogical Magazine, 62, 769-782.

Coltorti, M., Alberti, A., Beccaluva, L., Dos Santos, A.B., Mazzucchelli, M., Morais, E., Rivalenti, G. and Siena, F. (1993) The Tchivira-Bonga alkalinecarbonatite complex (Angola): petrological study and comparison with some Brazilian analogues. European Journal of Mineralogy, 5, 1001-1024.

Comin-Chiaramonti, P., Cundari, A., Piccirillo, E.M., de Barros Gomes, C., Castorina, F., Censi, P., De Min A., Marzoli, A., Speziale, S. and Velázquez, V.F. (1997a) Potassic and sodic igneous rocks from Eastern Paraguay: their origin from the lithospheric mantle and genetic relationships with the associated Paraná flood tholeiites. Journal of Petrology, 38, 495-528.

Comin-Chiaramonti, P., Cundari, A., Piccirillo, E.M., de Barros Gomes, C. and De Min, A. (1997b) Carbonatitic magmatism in the Paraná-Angola mantle plume(?) system: petrological and isotopegeochemical bearing on the source mantle. Eos, Transactions, $A G U, \mathbf{7 8}$, F741.

Comin-Chiaramonti, P., de Barros Gomes, C., Cundari, A., Castorina, F. and Censi P. (2007a) A review of carbonatitic magmatism in the Paraná-AngolaEtendeka system. Geophysical Research Abstracts, 9, 11507.

Comin-Chiaramonti, P., de Barros Gomes, C., Cundari, A., Castorina, F. and Censi, P. (2007b) A review of carbonatitic magmatism in the Paraná-AngolaNamibia (PAN) system. Periodico di Mineralogia, 76, 25-78.

Cooper, A.F. and Reid, D.L. (2000) The association of potassic trachytes and carbonatites at the Dicker Willem Complex, southwest Namibia: coexisting, immiscible, but not cogenetic magmas. Contributions to Mineralogy and Petrology, 139, 570-583.

de Carvalho, H. Tassinari, C., Alves, P.H., Guimarães, F. and Simões, M.C. (2000) Geochronological review of the Precambrian in western Angola: links with Brazil. Journal of African Earth Sciences, 31, 383-402.

Ercit, T.S., Hawthorne, F.C. and Černý, P. (1994) The structural chemistry of kalipyrochlore, a "hydropyrochlore". The Canadian Mineralogist, 32, 415-420.

Ernst, R.E. and Bell, K. (2010) Large igneous provinces (LIPs) and carbonatites. Mineralogy and Petrology, 98, 55-76.

Geisler, T., Berndt, J., Meyer, H.-W., Pollok, K. and Putnis, A. (2004) Low-temperature aqueous alteration of crystalline pyrochlore: correspondence between nature and experiment. Mineralogical Magazine, 68, 905-922.

Hogarth, D.D. (1977) Classification and nomenclature of the pyrochlore group. American Mineralogist, 62, 403-410.

Hogarth, D.D., Williams, C.T. and Jones, P. (2000) Primary zoning in pyrochlore group minerals from carbonatites. Mineralogical Magazine, 64, 683-697.

Issa Filho, A., Dos Santos, A.B.R.M.D., Riffel, B.F., Lapido-Loureiro, F.E.V. and McReath, I. (1991) Aspects of the geology, petrology and chemistry of some Angolan carbonatites. Journal of Geochemical Exploration, 40, 205-226.

Jago, B.C. and Gittins, J. (1991) The role of fluorine in carbonatite magma evolution. Nature, 349, 56-58.

Jago, B.C. and Gittins, J. (1993) Pyrochlore crystallization in carbonatites: the role of fluorine. South African Journal of Geology, 96, 149-159.

Lapido-Loureiro, F.E. de V. (1973) Carbonatitos de Angola. Memórias e Trabalhos do Instituto de Investigação Científica de Angola, 11, 1-242.

Laval, M., Johan, V. and Tourlière, B. (1988) La carbonatite de Mabounié: exemple de formation d'un gîte résiduel à pyrochlore. Chronique de la Recherche Minière, 56, 125-136.

Le Bas, M.J. (2008) Fenites associated with carbonatites. The Canadian Mineralogist 46, 915-932.

Lee, M.J., Lee, J.I., García, D., Moutte, J., Williams, C.T., Wall, F. and Kim, Y. (2006) Pyrochlore chemistry from the Sokli phoscorite-carbonatite complex, Finland: implications for the genesis of phoscorite and carbonatite association. Geochemical Journal, 40, 1-13.

Lottermoser, B.G. and England, B.M. (1988) Compositional variation in pyrochlores from the Mt. Weld carbonatite laterite, Western Australia. Mineralogy and Petrology, 38, 37-51.

Lumpkin, G.R. and Ewing, R.C. (1995) Geochemical alteration of pyrochlore group minerals: pyrochlore subgroup. American Mineralogist, 80, 732-743.

Lumpkin, G.R. and Mariano, A.N. (1996) Natural occurrence and stability of pyrochlore in carbonatites, related hydrothermal systems, and weathering environments. Materials Research Society Symposium Proceedings, (Scientific Basis for 
Nuclear Waste Management XIX), 412, 831-838.

Mitchell, R.H. and Kjarsgaard, B.A. (2004) Solubility of niobium in the system $\mathrm{CaCO}_{3}-\mathrm{CaF}_{2}-\mathrm{NaNbO}_{3}$ at $0.1 \mathrm{GPa}$ pressure: implications for the crystallization of pyrochlore from carbonatite magma. Contributions to Mineralogy and Petrology, 148, $281-287$.

Nasraoui, M. and Bilal, E. (2000) Pyrochlores from the Lueshe carbonatite complex (Democratic Republic of Congo): a geochemical record of different alteration stages. Journal of Asian Earth Sciences, 18, 237-251.

Nasraoui, M. and Waerenborgh, J.C. (2001) Fe speciation in weathered pyrochlore-group minerals from the Lueshe and Araxa (Barreiro) carbonatites by ${ }^{57} \mathrm{Fe}$ Mössbauer spectroscopy. The Canadian Mineralogist, 39, 1073-1080.

Nasraoui, M., Bilal, E. and Gibert, R. (1999) Fresh and weathered pyrochlore studies by Fourier transform infrared spectroscopy coupled with thermal analysis. Mineralogical Magazine, 63, 567-578.

Pichou, J.L. and Pichoir, F. (1984) A new model for quantitative X-ray microanalysis. Part I: application to the analysis of homogeneous samples. $L a$ Recherche Áerospatiale, 3, 13-38.

Platt, R.G. (1994) Perovskite, loparite and Ba-Fe hollandite from the Schryburt Lake carbonatite complex, northwestern Ontario, Canada. Mineralogical Magazine, 58, 49-57.

Renne, P.R., Ernesto, M., Pacca, I.G., Coe, R.S., Glen, J.M., Prevot, M. and Perrin, M. (1992) The age of Paraná flood volcanism, rifting of Gondwanaland, and the Jurassic-Cretaceous boundary. Science, 258,
975-979.

Renne, P., Ernesto, M. and Milner, S.C. (1997) Geochronology of the Paraná-Angola-Etendeka magmatic Province. Eos, Transactions, $A G U, \mathbf{7 8}$, F742.

Rocha, E., Nasraoui, M., Soubies, F., Bilal, E. and De Parseval, Ph. (2001) Geochemical evolution of pyrochlore during supergene alteration of Catalão II ore deposit. Comptes Rendus de l'Academie des Sciences, Série IIa: Sciences de la Terre et des Planetes, 332, 91-98.

Waber, N. (1992) The supergene thorium and rare-earth element deposit at Morro do Ferro, Poços de Caldas, Minas Gerais, Brazil. Journal of Geochemical Exploration, 45, 113-157.

Wall, F., Williams, C.T., Woolley, A.R. and Nasraoui, M. (1996) Pyrochlore from weathered carbonatite at Lueshe, Zaire. Mineralogical Magazine, 60, $731-750$.

Williams, C.T., Wall, F., Woolley, A.R. and Phillipo, S. (1997) Compositional variation in pyrochlore from the Bingo carbonatite, Zaire. Journal of African Earth Science, 25, 137-145.

Whitney, D.L. and Evans, B.D. (2010) Abbreviations for names of rock-forming minerals. American Mineralogist, 95, 185-187.

Woolley, A.R. (2001) Alkaline Rocks and Carbonatites of the World. 3. Africa. The Geological Society Publishing House, Bath, UK, 372 pp.

Yaroshevskii, A.A. and Bagdasarov Y.A. (2008) Geochemical diversity of minerals of the pyrochlore group. Geochemistry International, 46, 1245-1266. 
